\title{
PHẪU THUẬT ĐIỀU TRI THIẾU MÁU MẠN TÍNH CHI TRÊN: NHÂN MỘT TRƯỜNG HỢP VÀ NHİ̀ LẠI Y VĂN
}

\author{
Duơng Ngọc Thắng*, Đoàn Quốc Hung* Nguyễn Hũu Uớc**, Phùng Duy Hồng Sơn*
}

\section{TÓM TẮT}

Bệnh nhân nữ 52 tuổi, nhập viện vì đau và tê bì cẳng bàn tay trái liên tục do tắc động mạch cánh tay trái đã điều trị nội khoa 6 tháng không cải thiện. Bệnh nhân được phẫu thuật bắc cầu động mạch cánh tay một phần ba trên với động mạch trụ trái bằng tĩnh mạch hiển đảo chiều lấy từ cẳng chân trái. Kết quả lâm sàng cải thiện tốt sau phẫu thuật, chụp cắt lớp vi tính và siêu âm kiểm tra cho thấy cầu nối thông tốt. Giải phẫu bệnh cho thấy hình ảnh thâm nhiễm tế bào viêm ở lớp áo giữa thành mạch. Thiếu máu mạn tính chi trên là bệnh lý ít gặp với nguyên nhân đa dạng. Tiêu chuẩn chẩn đoán nguyên nhân là sinh thiết mạch trong mổ. Phẫu thuật tái lập tuần hoàn bằng cầu nối sử dụng vật liệu mạch máu tự thân mang lại kết quả tương đối tốt.

\section{SUMMARY: \\ BYPASS SURGERY FOR CHRONIC ISCHEMIA OF THE UPPER EXTREMITY: \\ ONE CASE-REPORT AND REVIEW OF LITERATURE}

52-year-old female, hospitalized for pain and numbness in her left forearm constantly due to left arm artery occlusion who had 6 months of medical treatment did not improve. The patient underwent an arterial bypass surgery between brachial artery and ulnar artery by autologousreversed greater saphenous vein. Clinical symptoms improved after surgery, computed tomography and ultrasound examination showed good result. The microbiopsy shows an image of an inflammatory cell infiltration in the tunica media of the vascular wall. Chronic ischemia of the upper extremity is a rare disease with diverse causes. The standard of diagnosis is vascular biopsy during surgery. Reconstructive vascular surgery using autologous vascular material provides good results.

\section{I. ĐẠTT VẤN ĐỀ}

So với bệnh lý động mạch chi dưới, các bệnh lý động mạch chi trên ít gặp hơn nhiều với sinh bệnh học tương đối da dạng và biểu hiện lâm sàng không điển hình. Tuy nhiên nguy cơ cắt cụt chi đối với những bệnh lý này lại không thấp. Hầu như tất cả các tổn thương giải phẫu bệnh học của động mạch đều có thể xuất hiện ở động mạch chi trên, nhưng đặc điểm giải phẫu và huyết động đặc biệt của chi trên thường gây khó khăn cho việc chẩn đoán. Đối với chi trên, tắc động mạch do huyết khối cấp tính hoặc do chấn thương gặp nhiều hơn so với tổn thương vữa xơ động mạch.Phẫu thuật tái lập tuần hoàn điều trị bệnh lý thiếu máu mạn tính chi trên là phẫu thuật rất ít gặp, chỉ chiếm 4\% trong số các phẫu thuật mạch máu [1] và chỉ được chỉ định khi đã điều trị nội khoa tối ưu và can thiệp mạch không có hiệu quả. Theo y văn, kết quả của phẫu thuật tạo cầu nối tái lập tuần hoàn chi trên tương đối tốt với tỉ lệ cầu nối còn thông sau 2 năm là $60-90 \%$ [2],[]]. Chúng tôi báo cáo trường hợp điều trị thành công thiếu máu mạn tính chi trên bằng phẫu thuật tạo cầu nối, từ đó đối chiếu với y văn, đưa ra các chỉ định trên lâm sàng và theo dõi kết quả điều trị.

\section{TRƯỜNG HợP LÂM SÀNG}

Bệnh nhân nữ 52 tuổi, nghề nghiệp làm ruộng, dân tộc Dáy, sinh sống tại Lào Cai, không phát hiện tiền sử bệnh lý cũng như chấn thương

\footnotetext{
* Trung tâm Tim mạch lồng ngực bệnh viện Hũu nghị Việt Đức, Đại học Y Hà Nội

Ngườ chịu trách nhiệm khoa họ: Dưong Ngọc Thắng

Ngày nhận bài: 02/08/2020 - Ngày Cho Phép Đăng: 04/09/2020

Phản Biện Khoa học: PGS.TS. Đặng Ngọc Hùng PGS.TS. Nguyễn Hũu Ước
} 
từ trước. Bệnh nhân nhập viện ngày 05/05/2020 với tình trạng đau và tê bì cẳng bàn tay trái liên tục kể cả ở trạng thái nghỉ ngơi. Khoảng nửa năm trước khi vào viện, bệnh nhân đã xuất hiện tình trạng đau cách hồi cẳng bàn tay khi làm việc, giảm đi nếu nghỉ ngơi. Bệnh nhân được khám và chẩn đoán tắc mạch cẳng tay trái mạn tính, điều trị nội khoa bằng Aspirin $100 \mathrm{mg} /$ ngày và Cilostazol200mg/ngày, các triệu chứng không cải thiện mà tiến triển nặng hơn sau 6 tháng.

Tại thời điểm nhập viện, bệnh nhân ổn định, mạch 70 lần/phút, huyết áp 110/70 mmHg. Tay trái teo cơ vùng cẳng tay, bàn tay lạnh nhợt hơn so với bên phải, mạch cánh tay, mạch quay và mạch trụ không bắt được. Các xét nghiệm huyết học, sinh hóa, động máu và miễn dịch nằm trong giới hạn bình thường. Siêu âm tim không phát hiện bất thường. Siêu âm hệ động mạch cảnh, hệ động mạch chi dưới và chi trên bên phải không phát hiện bất thường. Siêu âm mạch máu chi trên bên trái cho kết quả động mạch cánh tay một phần ba dưới huyết khối hoàn toàn, không có tín hiệu dòng chảy, động mạch quay và động mạch trụ phổ 1 pha, tốc độ dòng chảy giảm $10-15 \mathrm{~cm} / \mathrm{s}$. Chụp cắt lớp vi tính đa dãy có dựng hình (MSCT) mạch máu tay trái cho thấy hình ảnh huyết khối hoàn toàn đoạn hai phần ba dưới động mạch cánh tay, huyết khối động mạch quay và đoạn đầu động mạch trụ, giảm tưới máu bàn tay. [Hình 1]

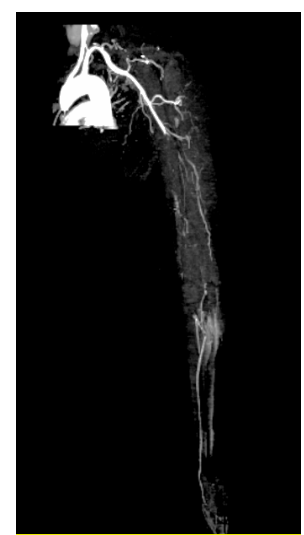

A

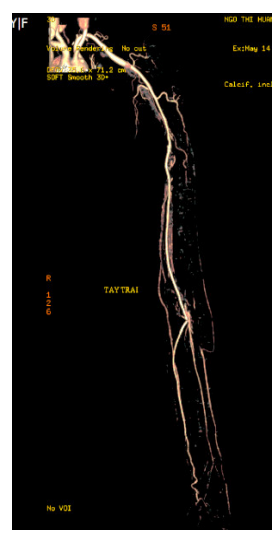

B
Hình 1. Chụp cắt lớp vi tính đa dãy có dựng hình mạch máu chi trên bên trái
A. Trước phẫu thuật;
B. Sau phẫu thuật

Bệnh nhân được phẫu thuật ngày 11/05/2020, phẫu thuật bắc cầu động mạch cánh tay một phần ba trên với động mạch trụ trái bằng tĩnh mạch hiển đảo chiều lấy từ cẳng chân trái. Kiểm soát mạch máu đầu ngoại vi bằng băng chun Esmarch. Các miệng nối giữa động mạch và tĩnh mạch hiển kiểu tận bên, chỉ prolene 6.0, 7.0 mũi vắt. Tạo đường hầm bằng dụng cụ dọc theo đường đi của động mạch cánh tay. Trong mổ thực hiện sinh thiết thành động mạch cánh tay đoạn có huyết khối. [Hình 2]

Sau phẫu thuật tình trạng bệnh nhân ổn định, bàn tay ấm, không còn cảm giác đau khi nghỉ, mạch trụ bắt rõ, mạch quay bắt yếu, các xét nghiệm huyết học và sinh hóa ngày thứ 2 sau mổ cho kết quả bình thường. Siêu âm kiểm tra ngày thứ 3 sau mổ kết quả cầu nối thông tốt, tốc độ dòng chảy $50 \mathrm{~cm} / \mathrm{s}$, động mạch quay và động mạch trụđoạn cổ tay có phổ và tốc độ trong giới hạn bình thường. Chụp MSCT mạch máu tay trái ngày thứ 3 sau mổ kiểm tra cho hình ảnh cầu nối thông tốt. Sinh thiết thành mạch cho thấy hình ảnh thâm nhiễm tế bào viêm ở lớp áo giữa mạch máu. Bệnh nhân được ra viện vào ngày thứ 4 sau phẫu thuật.Khám lại sau 1 tháng, bệnh nhân không còn dấu hiệu tê cẳng bàn tay, mạch trụ và mạch quay bắt rõ, siêu âm thấy hình ảnh hẹp đoạn đầu động mạch quay.

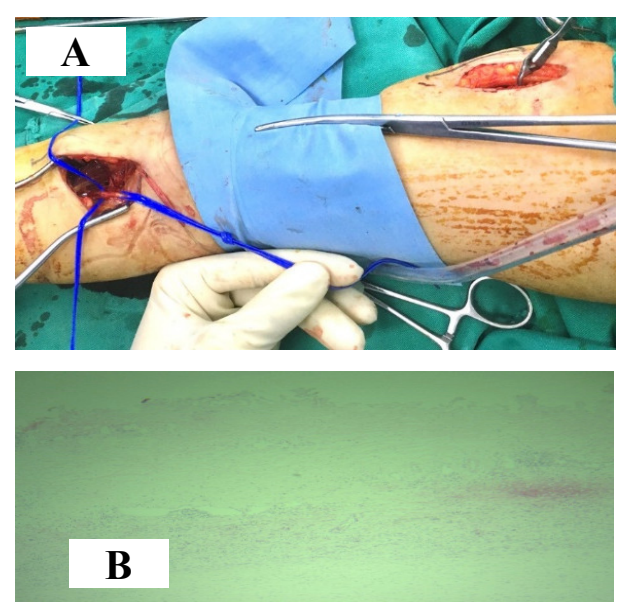

Hình 2. A. Cầu nối bằng tĩnh mạch hiển lớn đảo chiều

B. Hình ảnh vi thể thành mạch thâm nhiễm tế bào viêm 


\section{BÀN LUẬN}

Bệnh mạch máu chi trên mạn tính thường không biểu hiện triệu chứng lâm sàng. Các dấu hiệu lâm sàng gợi ý có thể là hiện tượng Raynaud, tình trạng đau dai dẳng ngọn chi cùng với teo búp ngón (dấu hiệu lâm sàng hay gặp nhất), hoặc dấu hiệu đau cách hồi chi trên hoặc bàn tay. Những dấu hiệu này có thể nhầm lẫn với tình trạng đau do thoái hóa đốt sống cổ hoặc thoát vị đĩa đệm gây chèn ép đám rối thần kinh cánh tay[4]. Sự phong phú của các nhánh tuần hoàn bàng hệ, khối lượng và kích thước cơ không lớn và nhu cầu lưu lượng máu đến cơ ở trạng thái hoạt động không cao là những lý do làm cho các biểu hiện lâm sàng của bệnh lý thiếu máu chi trên mạn tính không thực sự điển hình như ở chi dưới.Về mặt bệnh học có thể tóm tắt các nguyên nhân của bệnh lý động mạch chi trên như sau:

\section{Tắc mạch mạn tính sau huyết khối cấp} tính động mạch chi trên

Huyết khối xuất phát từ bệnh lý tim chiếm khoảng $90 \%$ các trường hợp thuyên tắc động mạch cấp tính, hai phần ba trong số đó có nguyên nhân từ rung nhĩ, $10 \%$ còn lại là huyết khối do loét mảng vữa xơ hoặc huyết khối trôi ra từ khối phồng mạch: loét xuyên thành động mạch chủ hoặc động mạch dưới đòn, hội chứng sườn cổ gây chèn ép động mạch dưới đòn, phồng động mạch nách [5]. Ngoài ra, các nguyên nhân khác như bệnh vữa xơ động mạch, các vi chấn thương hoặc viêm mạch cũng gây nên hiện tượng huyết tắc cấp tính tại chỗ. Do biểu hiện lâm sàng nghèo nàn hoặc không điển hình, bệnh nhân thường không đến khám hoặc có khám nhưng được chẩn đoán nhầm với các bệnh lý khác. Sau một thời gian, huyết khối tổ chức hóa và gây nên tình trạng tắc mạch mạn tính.

\section{Chấn thương mạch máu}

Những trường hợp chấn thương mạch máu gây thương tổn tắc mạch mạn tính đa số là những trường hợp bỏ sót thương tổn mạch máu, bao gồm vết thương hỏa khí hoặc bạch khí, chấn thương động mạch trực tiếp hoặc gián tiếp (gãy xương đòn, trật khớp vai, gãy trên lồi cầu xương cánh tay), tổn thương mạch do thầy thuốc gây nên (chọc động mạch can thiệp, đặt catheter động mạch, phẫu thuật vùng khớp vai). Một số nguyên nhân khác chiếm tỉ lệ nhỏ như lóc tách động mạch, chấn thương mạch do hoạt động thể thao và tổn thương mạch do tiêm chích [6],[7].

Các chấn thương nghề nghiệp cũng có thể gặp ở bệnh nhân làm nghề nghiệp đặc thù như thợ điêu khắc gỗ, thợ đẽo đá, thợ lấy củi...(công việc chịu lực nhiều và lặp lại ở vùng bàn tay). Tổn thương lâm sàng thường gặp là tắc mạch vùng bàn - ngón tay hoặc phồng động mạch trụ đoạn cổ tay [4]. Tuy nhiên ở Việt Nam, nhóm bệnh lý này lại chưa được quan tâm đến chẩn đoán và điều trị.

\section{Bệnh lý động mạch dưới đòn}

Bệnh lý chủ yếu của động mạch dưới đòn là vữa xơ động mạch. Tổn thương tương đối thường gặp (chiếm $2 \%$ dân số nói chung và $7 \%$ trong số các bệnh nhân thiếu máu chi trên mạn tính). Vị trí tổn thương chủ yếu là đoạn động mạch dưới đòn trước chỗ chia ra động mạch đốt sống và tỉ lệ tổn thương động mạch dưới đòn trái nhiều hơn bên phải [8]. Đại đa số các trường hợp hẹp tắc đoạn đầu động mạch dưới đòn không có chỉ định can thiệp. Chỉ có 2 trường hợp đặc biệt có chỉ định can thiệp đối với tổn thương động mạch dưới đòn: trường hợp thứ nhất là đối với các bệnh nhân suy thận mạn có thông động tĩnh mạch cùng bên với bên hẹp động mạch dưới đòn và bệnh nhân có cầu nối chủ vành bằng động mạch ngực trong bên trái; trường hợp thứ hai là các bệnh nhân mắc bệnh Takayasu với tổn thương dày thành đoạn gốc động mạch dưới đòn.

\section{Bệnh lý động mạch nách và cánh tay}

Ở vùng này chủ yếu tổn thương mạch máu nằm trong bệnh cảnh bệnh lý Horton hoặc dị sản xơ cơ thành mạch. Tỉ lệ tổn thương mạch máu chi trên do bệnh lý Horton cao hơn hẳn so với chi dưới (10-15\% so với 1\%) [9]. 


\section{Bệnh lý động mạch vùng cẳng tay}

Bệnh lý mạch máu vùng này có thể nằm trong bệnh cảnh bệnh Burger, các bệnh nghề nghiệp, bệnh mạch do hút thuốc lá hoặc cần sa (tắc mạch do vi huyết khối).

Bệnh nhân trong nghiên cứu này được chẩn đoán tắc mạch mạn tính chi trên dựa vào kết quảsinh thiết mạch máu với hình ảnh thâm nhiễm bạch cầu đa nhân và và lympho bào ở lớp áo giữa thành mạch. Đây là bệnh lý hiếm gặp với tỉ lệ mắc 0,017 đến $0,046 \%$ dân số, độ tuổi mắc bệnh chủ yếu từ 50-70 tuổi [10]. Tổn thương viêm mạch hay gặp ở động mạch cảnh ngoài và các nhánh của nó, đặc biệt là động mạch thái dương nông, tổn thương ở động mạch chi trên hoặc chi dưới chỉ gặp ở từ 3 đến $16 \%$ số bệnh nhân mắc bệnh này [11],[12].

Phẫu thuật tái lập tuần hoàn điều trị bệnh lý thiếu máu mạn tính chi trên là phẫu thuật rất ít gặp, chỉ chiếm 4\% trong số các phẫu thuật mạch máu [1]. Các nghiên cứu trên thế giới cũng chỉ báo cáo hồi cứu một số ít trường hợp trong khoảng thời gian dài 10-15 năm [13],[14]. Nhìn chung, chỉ định phẫu thuật làm cầu nối tái lưu thông mạch máu chi trên gồm có đau cánh - cẳng - bàn tay khi vận động hoặc khi nghỉ ngơi, xuất hiện hoại tử tổ chức bàn - ngón tay[14],[15]. Về nguyên tắc có thể sử dụng các loại vật liệu sau làm cầu nối mạch máu: mạch máu tự thân, mạch máu khác loài, mạch máu đồng loài hoặc vật liệu nhân tạo. Sử dụng tĩnh mạch hiển lớn luôn là sự lựa chọn hàng đầu của chúng tôi, báo cáo của Spinelli và đồng nghiệp cho thấy, tĩnh mạch hiển lớn được sử dụng trong 16/20 trường hợp làm cầu nối $(80 \%)$ [14]. Chúng tôi sử dụng kỹ thuật rạch da theo suốt chiều dài của tĩnh mạch để lấy, so với kỹ thuật rạch da cách quãng, kỹ thuật này để lại thương tổn da và phần mềm nặng hơn đồng nghĩa với nguy cơ nhiễm trùng và chảy máu sau mổ tăng lên nhưng tĩnh mạch thu được lại ít bị sang chấn hơn. Trong trường hợp tĩnh mạch hiển lớn đã được sử dụng để làm cầu nối cho mạch máu chi dưới, tĩnh mạch đầu và tĩnh mạch nền vùng cánh - cẳng tay cũng có thể được sử dụng. Mạch nhân tạo không phải là vật liệu được ưu tiên sử dụng nhất là đối với mạch máu vùng cẳng tay do kích thước và nguy cơ tắc cầu nối sớm sau phẫu thuật khá cao. Theo một số nghiên cứu, phẫu thuật cắt hạch giao cảm cổ ngực có thể thúc đẩy quá trình liền sẹo đối với các vết loét vùng ngón tay khi kết hợp với phẫu thuật tái lưu thông bằng cầu nối hoặc thực hiện riêng lẻ [16]. Chúng tôi chưa có kinh nghiệm sử dụng phẫu thuật này để điều trị bệnh nhân thiếu máu chi trên mạn tính. Về kết quả phẫu thuật điều trị thiếu máu mạn tính chi trên bằng cầu nối, các nghiên cứu trên thế giới đều cho thấy tỉ lệ cầu nối thông tốt trong khoảng thời gian 1-3 năm sau phẫu thuật là trên $80 \%$ [13],[14],[15].

\section{KẾT LUẬN}

Tắc mạch mạn tính chi trên là bệnh lý ít gặp với thương tổn không điển hình và nguyên nhân đa dạng. Tiêu chuẩn chẩn đoán nguyên nhân là sinh thiết mạch trong mổ đối với những trường hợp có chỉ định phẫu thuật. Phẫu thuật tái lập tuần hoànbằng cầu nối sử dụng vật liệu mạch máu tự thân phối hợp với điều trị nguyên nhân bằng nội khoa mang lại kết quả tương đối tốt, góp phần cải thiện chất lượng cuộc sống, sinh hoạt và lao động của người bệnh.

\section{TÀI LIỆU THAM KHẢO}

1. Bergqvist D, Ericsson B.F., Konrad Pet al. (1983). Arterial surgery of the upper extremity. World J Surg, 7, 786-791.

2. Mesch C.L., McCarty W.J., Pearce W.H.et al. (1993). Upper extremity bypass grafting. A 15-years experience. Arch Surg, 128, 795-801.

3. Brunkwall J, Bergqvist D, Bergentz S.E. (1994). Long-term results of arterial reconstruction of the upper extremity. Eur J Vasc Surg, 8, 47-51.

4. F. Becker (2007). Artériopathies du membre supérieur. Rev Med Suisse, 3, 306-311. 
5. Porter JM, Taylor LM (1994). Basic data underlying clinical decision making in vascular surgery, Quality Medical Publishing, Missouri.

6. Caiati JM, Masters CM, Todd Eet al. (2000). Symptomatic axillary artery dissection in a tennis player. Am J Sports Med, 28, 411-412.

7. Uder M Scheffler P, Gross J, et al (2003). Dissection of the proximal subclavian artery with consecutive thrombosis and embolic occlusion of the hand arteries after playing golf. Am J Sports Med, 31, 137-140.

8. Shadman R, Criqui M, Bundens Wet al. (2004). Subclavian artery stenosis : Prevalence, risk factors and association with cardiovascular diseases. JACC, 44, 618-623.

9. Skopinski S, Constans J, Cherifi Het al. (1999). Artériopathie inflammatoire des membres supérieurs au cours de la maladie de Horton. $J$ Mal Vasc, 24, 45-48.

10. Assie C, Janvresse A, Plissonnier Det al.(2011). Longterm follow-up of giant cell arteritis. A series of 36 patients. Medicine (Baltimore), 90, 40-51.

11. Bengtsson BA, Malmvall BE (1981). Prognosis of giant cell arteritis including temporal arteritis and polymyalgia rheumatica. A follow-up study on ninety patients treated with corticosteroids. Acta Med Scand, 209, 337-345.

12. Greene GM, Lain D, Sherwin RMet al. (1986). Giant cell arteritis of the legs. Clinical isolation of severe disease with gangrene and amputations. Am J Med, 81, 727-733.

13. Kakra Hughes, Allen Hamdan, Marc Schermerhornet al. (2007). Bypass for chronic ischemia of the upper extremity: Results in 20 patients. Journal of vascular surgery, 46, 303-307.

14. F. Spinelli, F. Benedetto, G. Passariet al.(2010). Bypass Surgery for the Treatment of Upper Limb Chronic Ischaemia. Eur $J$ Vasc Endovasc Surg, 39, 165-170.

15. Roddy SP, Darling 3rd RC, Chang BBet al. (2001). Brachial artery reconstruction for occlusive disease: a 12-year experience. $J$ Vasc Surg, 33, 802-805.

16. Raposio E, Filippi F, Renzi Met al. (2001). Minimally-invasive endoscopic transthoracic sympathectomy of the upper limbs. Minerva Chir, 56, 193-197. 